\title{
Horkheimer leitor de Schopenhauer: uma tradução e um breve comentário
}

\author{
Flamarion Caldeira Ramos \\ Doutorando do Departamento de Filosofia \\ da Universidade de São Paulo
}

Resumo: Apresenta-se aqui um breve comentário introdutório à tradução de O pensamento de Schopenhauer em relação à ciência e à religião (1971) de Horkheimer. Trata-se apenas de indicar o lugar e a importância desse texto na filosofia tardia de Horkheimer e mostrar, com isso, as diferentes abordagens que o fundador da Teoria Crítica oferece do pensamento de Schopenhauer e do pessimismo.

Palavras-chave: Horkheimer, Schopenhauer, pessimismo, filosofia, ciência, religião
Abstract: This paper presents a brief introduction to Horkheimer's The thought of Schopenhauer Concerning Science and Religion (1971) by indicating the role and the importance of this text in Horkheimer's late philosophy, as well as the several approaches of Schopenhauer's thought throughout his work.

Key-Words: Horkheimer, Schopenhauer, pessimism, philosophy, science, religion

O pensamento de Schopenhauer em relação à ciência e à religião, de 1971, foi o último de cinco textos que Horkheimer publicou em vida sobre a filosofia de Schopenhauer. Além dele, Horkheimer pronunciou outras quatro conferências na sede da Schopenhauer Gesellschaft em Frankfurt: Schopenhauer e a sociedade (1955), A atualidade de Schopenhauer (1961), Religião e Filosofia (1967) e Pessimismo hoje (1969). Do primeiro ao último texto é possível notar algumas diferenças fundamentais na abordagem de Horkheimer, pois, se fica clara a vinculação entre os primeiros textos e as reflexões críticas sobre a "razão instrumental" e a "sociedade administrada", marcantes no pensamento do Horkheimer do pós-guerra, nos últimos é evidente o parentesco com os temas da assim chamada filosofia tardia de Horkheimer, que flerta com 
uma recuperação da teologia por meio da temática do "anseio pelo inteiramente outro". Para compreender o que está em jogo nesses textos, portanto, temos de ver como o motivo do pessimismo se desenvolve ao longo da obra de Horkheimer.

Seguindo a indicação de F. Werner Veauthier, podemos esboçar ao menos cinco posições ao longo do desenvolvimento intelectual de Horkheimer nas quais o "motivo do pessimismo" se faz presente. ${ }^{1}$ Em primeiro lugar, posições fundamentalmente pessimistas formam desde o início um elemento constante no pensamento de Horkheimer, por mais que se queira ver o pessimismo da fase tardia como uma radical mudança em relação às posturas críticas da década de 30. Esse elemento se refere ao caráter infundado da busca da felicidade, do sofrimento da natureza, das dores do passado e da transitoriedade do presente. Por isso, apesar de todo otimismo que possa ter o materialismo com relação à mudança das condições,

apesar de toda a valorização da felicidade que brota do esforço por mudança e da solidariedade, ele carrega consigo um traço pessimista. A injustiça passada é irremediável. Os sofrimentos das gerações passadas não encontram nenhuma compensação. ${ }^{2}$

1. Cf. Veauthier, F. W. "Zur Transformation der Pessimismus-Motive im Denken Max Horkheimers". In: Schopenhauer Jahrbuch, no 73. Frankfurt am Main, 1988, pp. 593-607. Para Veauthier, o "motivo pessimista" ou "motivo schopenhaueriano", efetivamente presente em todas as fases do pensamento de Horkheimer, é "o interesse no sofrimento humano, em sua causa e na possibilidade de sua supressão. 'Pois, que milhares tenham vivido na felicidade e no bem-estar, isso não suprime a angústia e o martírio de um único'. Essa convicção de Schopenhauer ficou profundamente impregnada na filosofia social de Horkheimer, mesmo se ele não pudesse compartilhar de sua suposição metafísica fundamental de um querer existir que causa o sofrimento". Idem, p. 593. Deve-se entender aqui por motivo, segundo Veauthier, algo diferente de "argumento", o que não quer dizer que ele seja irredutível a qualquer verificação racional. Ele é, ao mesmo tempo, ponto de partida (Beweg-Grund) do pensamento, mas também causa real do desenvolvimento social. Cf. Idem, p. 595.

2. Horkheimer, M. Materialismo e Metafísica. In:___. Teoria Crítica I. Trad. de Hilde Cohn. São Paulo: Perspectiva, 2006, p. 43. Cf. Post, W. Kritische Theorie und metaphysischer Pessimismus. Zum Spätwerk Max Horkheimers. München: 1971, p. 37. 
O pessimismo aqui não se refere a uma teoria catastrófica, apocalíptica em relação ao presente e ao futuro, mas a fatos do passado, algo que não pode ser mais resgatado. Essa experiência do pessimismo não contradiz a convicção no caráter socialmente condicionado do bem estar humano, pois também o sofrimento é causado por relações sociais e como tal deve ser combatido. Nesse sentido, o pessimismo também se compreende como socialmente condicionado, pois diz respeito a uma sociedade em que a solidariedade com aqueles que ela exclui, com os pobres e injustiçados, é negada: o pessimismo é, portanto, negação da solidariedade negada. Se é assim, então o pessimismo de Horkheimer se distancia, pelo menos em sua fase inicial, de um pessimismo autocomplacente referido ao próprio sujeito, constantemente qualificado de "romântico", pois tenta unir a convicção de que "o núcleo mesmo da vida é o sofrimento e a morte" com a solidariedade presente na crítica social que visa a emancipação. Seria então essa convicção que justificaria a seguinte afirmação posterior de Horkheimer?

O pessimismo metafísico, momento implícito em todo pensamento genuinamente materialista, me foi familiar desde sempre. À obra de Schopenhauer devo meu primeiro contato com a filosofia: a relação com a doutrina de Hegel e de Marx, o desejo de compreender e de mudar a realidade social não resgataram, apesar do contraste político, minha experiência com a sua filosofia. ${ }^{3}$

3. Horkheimer, M "Prefácio para a reedição de Teoria Crítica I" (1968). In: . Teoria Crítica I, p. 4. Este prefácio, escrito em 1968, já indica, porém, algumas diferenças fundamentais sobre a questão da relação entre teoria e prática no pensamento de Horkheimer. Assim, diz o autor na seqüência do texto citado: "A sociedade melhor, a sociedade justa, é uma meta que se mistura com a idéia de culpa. Desde o fim da guerra, porém, a meta mudou. A sociedade se encontra em nova fase. Característicos da estrutura da camada superior já não são os capitalistas concorrentes, mas o empresariado, as associações, os comitês; a situação material dos dependentes suscita tendências políticas e psicológicas diferentes das do antigo proletariado". (Idem, Ibidem). Essa passagem revela claramente o quanto as mudanças fundamentais entre as abordagens sobre a relação entre a teoria e a prática no pensamento de Horkheimer dependem de sua visão do capitalismo e da democracia no pós-guerra. Evidentemente, esse não será o tema deste breve 
Um segundo momento seria aquele caracterizado pelos textos do pós-guerra que se dirigem especialmente a uma crítica da razão: a Dialética do Esclarecimento (em parceria com Adorno) e o Eclipse da razão. A idéia do esclarecimento, essencial para o processo emancipatório, é considerada um fracasso, e Horkheimer afirma a posição pessimista de um declínio latente da razão. Trata-se agora do tema da perversão da razão que, em vez de levar à emancipação do homem, conduziu a uma dominação da natureza e a um mundo totalmente administrado que tem como conseqüências o declínio do indivíduo e a revolta da natureza. Esse novo diagnóstico potencializa o motivo pessimista, pois agora justamente aquela instância que poderia levar o homem à compreensão das injustiças, e assim dar o primeiro passo para a transformação das relações sociais injustas, é posta em cheque. Embora não chegue a afirmar um pessimismo metafísico, que estabeleceria causas a-históricas e intemporais para o mal no mundo - pelo contrário, Horkheimer recusa terminantemente o recurso a tal argumentação -, o autor não deixa de refletir sobre os fundamentos que levaram a uma tal situação. O que toma forma no pensamento de Horkheimer agora não é somente um pessimismo com relação à técnica, uma tecnofobia, mas a idéia segundo a qual a razão subjetiva, que transforma a razão num mero instrumento, corrói de maneira fatal a razão objetiva. Disso é conseqüência a falência dos sistemas objetivos da razão, que ainda tentavam dar voz às necessidades mais essenciais do homem e da natureza, e em seu lugar entra o mero cálculo e a transformação dos meios em fins. Esse talvez seja o momento mais importante da leitura horkheimiana de Schopenhauer, pois sem dúvida este último serviu de inspiração ao primeiro na medida em que Schopenhauer já considerava a razão, desvinculada de qualquer preocupação com o conhecimento objetivo, como um mero instrumento para servir à vontade de viver. ${ }^{4}$

comentário, que visa apenas esboçar um quadro sobre os pontos principais da leitura de Horkheimer sobre Schopenhauer ao longo de sua obra.

4. Cf. Chiarello, M. G. Das Lágrimas das coisas. Estudo sobre o conceito de natureza em Max Horkheimer. Campinas: Editora da Unicamp, 2001, p. 261 e ss. 
Como conseqüência dessa situação e em contraste com o crescimento econômico e o Estado de bem-estar social, é possível notar nos apontamentos tardios (Notizen: 1949-1973) uma expansão do sentimento de desilusão com as promessas emancipadoras da atividade de crítica e transformação da sociedade. Este seria o terceiro momento do pessimismo em Horkheimer. O retrocesso da autonomia do sujeito individual, o desvanecimento da fantasia e da criatividade expressam uma situação social indigna e niveladora. Neste cenário é que se dá uma volta aos textos de Schopenhauer e uma desconfiança com relação ao pensamento dialético de Hegel e Marx. É o que se pode notar nas conferências Schopenhauer e a sociedade (1955) e A atualidade de Schopenhauer (1961). Inicialmente, o autor de Teoria Tradicional e Teoria Crítica prefere ressaltar os aspectos inconformistas da moral schopenhaueriana e seu caráter crítico em relação ao idealismo de Hegel. A atualidade e o valor do radicalismo moral de Schopenhauer, segundo Horkheimer, consistem em sua insistente recusa de qualquer conciliação idealista em que o sofrimento encontre sua justificação. Dessa atitude é sintomática sua concepção nada divina do Estado que, antes de ser uma instituição moral, repousa no "egoísmo esclarecido" dos indivíduos, não sendo mais que uma instituição protetora em relação aos ataques externos e internos. Assim, Schopenhauer não teria

endeusado nada, nem o Estado nem a técnica; o desenvolvimento do intelecto se apóia no desenvolvimento das necessidades; e os promotores máximos das ciências foram a fome, o instinto de poder e a guerra: a fábula idealista acerca da astúcia da razão, mediante a qual o horror do passado se vê tanto embelezado como mitigado graças ao bom final, deixa que se filtre a verdade sobre o sangue e a miséria que acompanham os triunfos da sociedade, e o resto é ideologia. ${ }^{5}$

5. Horkheimer, M. Voträge und Aufzeichnungen 1949-1973. In: Gesammelte Schriften. vol. 7. Org. de A. Schmidt. Frankfurt: $\overline{\text { Fischer }}$ Taschenbuch Verlag, 1985, pp. 124-5. Edição espanhola: Horkheimer, M. "Schopenhauer y la Sociedad". In: Adorno, T. W.; Madrid: Taurus, 1971, p. 168. 
A revalorização que Horkheimer oferece do pensamento de Schopenhauer se deve ao reconhecimento de que nenhuma construção teórica pode estar acima do sofrimento de cada criatura num mundo que prossegue dominado pela contradição e pela dor. É assim que ele julga Schopenhauer como um "pessimista clarividente" que acabou sendo confirmado pela história no século XX; sua negação do curso do mundo é o reconhecimento da experiência de que nenhuma astúcia da razão pode justificar um mundo absurdo. A violência da história faz o homem recuar diante de qualquer esperança de emancipação, e o que tem lugar então é a experiência do horror histórico:

a doutrina de Schopenhauer põe ante a vista do que se trata: os interesses materiais, a luta pela existência, o bem-estar e o poder formam o motor; a história o resultado. Schopenhauer não racionalizou filosoficamente a experiência do horror e da injustiça que se dá até nos países que são governados do modo mais humano; teve medo da história; lhe repugnavam as mudanças políticas violentas que tentaram levar a cabo na época contemporânea com ajuda de uma exaltação nacionalista. ${ }^{6}$

É assim que Horkheimer, em especial a partir dos anos 60, insiste, contra Hegel e contra qualquer espécie de idealismo, na inadequação essencial entre o conceito e seu objeto. $\mathrm{O}$ espírito deve cobrar consciência de que o mundo vive dominado pela contradição e pela dor, mas, ao chegar a esse ponto, deve sucumbir, e não erigir-se em sistema de pensamento capaz de salvar a positividade do absoluto, nele incluindo a tortura e a morte. ${ }^{7}$ Estabelecese então a tarefa da filosofia, de dar voz ao sofrimento, e a recusa de conciliar a dor com qualquer falsa totalidade. A filosofia deve expressar, portanto, uma experiência, e essa experiência é a do sofrimento, pois somente a contemplação do mal pode fundar a solidariedade e o impulso de pôr-lhe fim. Maurício Chiarello mostra

6. Horkheimer,M.Voträgeund Aufzeichnungen 1949-1973.In:___. Gesammelte Schriften, p. 125. Edição Espanhola: Horkheimer, M. "Schopenhauer y la Sociedad”. In: Adorno, T. W.; __ Sociologica, p. 169.

7. Cf. Schmidt, A. Drei Studien über Materialismus. Schopenhauer, Horkheimer, Glücksproblem. Munique: Carl Hanser Verlag, 1977, pp. 8-9. 
como a obra de Schopenhauer passa a ter um papel fundamental no pensamento de Horkheimer, quando este se desencanta com as promessas emancipadoras da dialética. $\mathrm{O}$ materialismo dialético teria falhado ao representar o Bem supremo sobre a face da terra como realização não somente possível no decorrer do processo histórico, mas mesmo logicamente necessária. Chiarello resume a aproximação de Horkheimer a Schopenhauer:

Atual é Schopenhauer, assinala Horkheimer, porque hoje, mais ainda do que em seu tempo, o progresso da civilização demonstrou ser aquilo que, em sua obra, já se desmascarava em sentenças tão inconformadas quanto amargas. Saltava-lhe aos olhos que a marcha triunfal do progresso não passava da manifestação da Vontade inconsciente de si mesma em sua crueza irracional e autodevoradora. Repetirá, incansável, que o processo histórico é uma eterna repetição do mesmo com outros nomes e sob outras roupagens. E contudo, nessa clarividência esteve sozinho. Contra toda sua época, que em uníssono idolatrou a história como contínua e necessária progressão rumo ao melhor, Schopenhauer escreveu como um profeta a maldizer seu tempo, enquanto seus contemporâneos deixavam seu vaticínio cair no vazio. Seu grande valor: o de não ter sucumbido a nenhuma tentativa de racionalizar o horror e a injustiça reinantes na história. Foi lúcido e honesto o bastante para discernir, por trás da apologia do progresso a qualquer preço, mais um ardil da razão a disfarçar o interesse material, o afã da existência, bem-estar e poder que governam a história. Compreendeu melhor do que ninguém em seu tempo que todo progresso pagava-se com novas penas, para cuja realização impunha-se a representação de algo melhor. ${ }^{8}$

Já no final dos anos 60 a leitura de Horkheimer inicia um novo movimento. Se temos agora, por um lado, uma confirmação do processo contínuo de reificação que acarreta a decadência da cultura burguesa e que se expressa na perda de sentido da autoridade, da família e de valores como o amor e o respeito, temos, por outro, uma abertura a temas que escapam da crítica social e se aproximam da filosofia da religião e da teologia. As três últimas

8. Chiarello, M. G. Das Lágrimas das coisas. Estudo sobre o conceito de natureza em Max Horkheimer, p. 195-6. 
conferências de Horkheimer sobre Schopenhauer desenvolverão esses dois temas. E essas são as duas últimas figuras do pessimismo em Horkheimer, embora a última delas pareça flertar com uma simbólica esperança numa ordem diferente de coisas. Essa esperança, entretanto, não se baseia em nenhuma crença sobrenatural, mas no anseio, que permanece mero anseio, de que a injustiça não seja a única a triunfar. Trata-se de uma esperança que surge da experiência do mal, como possibilidade última de sua superação. Em Schopenhauer há realmente algo próximo disso, em sua teoria da negação da vontade de viver. Por isso, para Horkheimer, no quadro do capitalismo tardio e da dissolução da razão substancial, a filosofia de Schopenhauer permanecerá um consolo: "em contraste com a mentalidade atual, sua metafísica oferece a mais profunda fundamentação da moral, sem entrar em contradição com o conhecimento científico". ${ }^{9}$ Segundo Horkheimer, os argumentos da filosofia pessimista de Schopenhauer que apóiam o cristianismo são mais plausíveis que os argumentos da ontoteologia racionalista de autores como Descartes ou Leibniz, ou do criticismo kantiano, que retoma as crenças cristãs na existência de um Deus bondoso e na imortalidade da alma por meio da doutrina dos postulados da razão prática. ${ }^{10}$ Aqui Horkheimer parece concordar inteiramente com a tese de Schopenhauer segundo a qual sua filosofia deve ser considerada a autêntica filosofia cristã. ${ }^{11}$ Mas qual a interpretação que Schopenhauer tem do cristianismo que o permite julgar que sua filosofia, mesmo atéia e imanente, é a filosofia própriamente cristã?

Os dois pontos principais que fazem Schopenhauer aproximar sua filosofia da religião cristã são: a idéia do pecado original, da queda do homem que permite interpretar o mundo como um "vale de lágrimas", e a idéia da redenção do mundo pelo sofrimento, como apresentado na paixão de Cristo. Em sua metafísica,

9. Horkheimer, M. Schopenbauers Denken im Verbältnis zu Wissenschaft und Religion. In:__. Gesammelte Schriften, vol. 7 (Voträge und Aufzeichnungen 1949-1973), pp. 251-2.

10. Horkheimer, M. Religion und Pbilosophie. In: ___ Gesammelte Scbriften, vol. 7, p. 193.

11. Idem, ibidem. Cf. Schopenhauer, A. Parerga e Paralipomena, § 163, In: Coleção "Os Pensadores". São Paulo: Abril Cultural, 1980, p. 229. 
Schopenhauer oferece uma visão da existência carregada de negatividade, o que se fundamenta em sua concepção da vontade como a essência íntima das coisas, o substrato de todos os fenômenos, a coisa em si de Kant. O mundo dos fenômenos, que se apresenta na experiência, é regido pelo princípio de razão que sempre relaciona um efeito a uma causa em todo evento espaço-temporal, e é o que torna esse mundo da representação uma série necessária de acontecimentos determinados. Assim como em Kant, o entendimento, que unifica a multiplicidade sensível, aparece como o princípio que torna a experiência do mundo relativa à nossa capacidade de conhecer. Para além desse mundo dado na intuição empírica deve haver algo mais substancial, pois, se toda a realidade se esgotasse nos fenômenos, o mundo inteiro não se distinguiria dos sonhos e o idealismo absoluto seria justificado. Para além dos fenômenos, porém, Schopenhauer compreende a vontade como a essência permanente das coisas, constituinte da realidade substancial do mundo dado na intuição empírica.

Estabelecida a Vontade como a coisa em si, resta indicar quais as conseqüências éticas com as quais essa filosofia se depara. Se este mundo é a objetivação da vontade de viver, ele é então o palco da afirmação de si mesma dessa vontade, e tudo o que acontece neste mundo não pode ser senão a realização desse querer. Quando é afirmada essa vontade de vida, o que se afirma é esta vida que temos diante dos olhos no mundo, e, para saber o que quer essa vontade infnita, basta-nos ver o que o próprio mundo é. Como não existe causa fora do domínio do princípio de razão, apenas se pode dar a razão dos fenômenos, não da própria vontade. "De fato, a ausência de toda finalidade e de todo limite pertence à essência da Vontade em si, que é um sem fim". ${ }^{12} \mathrm{Um}$ eterno devir, um escoamento perpétuo é o que caracteriza a vontade de viver. As características perturbadoras que a vida em geral assume são todas decorrentes da essência da vontade. Segundo

12. Schopenhauer, A. O mundo como vontade e representação. In: Sämtliche Werke. Editadas e comentadas criticamente por Arthur Hübscher. Wiesbaden: F. A. Brockhaus, 1972, vol II. § 28, p. 195. Edição brasileira: Schopenhauer, A. O mundo como vontade e representação. Trad. de Jair Barboza. São Paulo: Unesp, 2005, p. 230. 
Schopenhauer, a Vontade, em todos os seus graus de manifestação, tem falta total de uma finalidade última, deseja sempre, sendo o desejo todo o seu ser. É por isso que só podemos conceber os seres do mundo num estado de perpétua dor, sem felicidade durável. Isso porque todo desejo é sofrimento enquanto não é satisfeito, pois nasce duma falta. Como não existe fim último para o esforço, não existe termo para o sofrimento. No reino animal vemos a infinita diversidade de formas, as modificações incessantes às quais elas se submetem para apropriar-se do meio, também a arte inimitável e igualmente perfeita em todos os indivíduos que preside a sua estrutura e seu mecanismo, a inesgotável quantidade de força que eles empregam, tudo isso em favor da conservação de suas respectivas espécies. Mas não vemos como resultado mais que a satisfação da fome e do instinto sexual, e talvez alguns curtos momentos de bem-estar.

Se se considera, de uma parte, a engenhosidade inexprimível do empreendimento, a riqueza indizível dos meios e, de outro, a pobreza do resultado perseguido e obtido, então nos impele a admissão de que a vida é um negócio cujos lucros não cobrem, nem de longe, os gastos. ${ }^{13}$

A vida do homem também não se apresenta de forma alguma como uma dádiva, mas sim como uma tarefa, como uma dívida da qual devemos livrar-nos. No todo ou em detalhe, o que vemos não é senão miséria universal, fadiga sem trégua, atividades forçadas, lutas sem fim, mas a finalidade de tudo isso consiste apenas em assegurar durante um curto espaço de tempo a existência de indivíduos efêmeros e atormentados. ${ }^{14}$

Diante de tal quadro a afirmação da vida seria a aceitação desse espetáculo - "belo de se ver", é verdade. "Mas ser é bem outra coisa". ${ }^{15}$ Já a negação da vontade tem o sentido de uma recusa e, por isso, é uma atitude moral. Aquele que nega é aquele que, ao

13. Schopenhauer, A. O mundo como vontade e representação. Complementos, Cap. 28.In: Sämtliche Werke, vol. III, p. 403.

14. Idem, p. 407.

15. Idem, p. 665. 
tomar para si todas as dores do mundo, não pode mais afirmar o sofrimento essencial à vida. Dessa forma, não basta negar o fenômeno, mas a própria essência. A negação da vontade, no entanto, não surge a partir do sofrimento com a necessidade do efeito saído de uma causa, mas a vontade permanece livre. Aqui se trata de uma "conversão transcendental", já que esse é o único ponto em que a liberdade da vontade se expressa no fenômeno. ${ }^{16}$ Daqui em diante, o autor se utiliza de expressões emprestadas da mística e da religião, cristã e oriental, para expressar seu pensamento.

Aquilo a que os místicos cristãos chamam efeito da graça e renascimento é para nós a única manifestação imediata da liberdade da vontade. Ela se produz apenas quando a vontade, após alcançar o conhecimento de sua essência em si, obtém um quietivo e é subtraída da ação dos motivos, ação que depende de um outro modo de conhecimento em que os objetos são apenas fenômenos. ${ }^{17}$

Para entender esse processo, entretanto, falta qualquer conceito, resta apenas a linguagem simbólica das religiões. Schopenhauer opõe o homem natural ao santo, o reino da natureza, regido pela necessidade, ao reino da graça, o reino da liberdade. ${ }^{18} \mathrm{~A}$ identidade de todos os seres só pode se dar no domínio da negação da vontade (Nirvana), pois no domínio da afirmação (Samsara) só há multiplicidade. ${ }^{19}$ Segundo a teologia cristã interpretada por

16. Cf. Schopenhauer, A. O mundo como vontade e representação, § 68. In: Sämtliche Werke.vol. II, p. 467.

17. Schopenhauer, A. O mundo como vontade e representação, § 70. In: Sämtliche Werke.vol. II, p. 478. Edição brasileira: Schopenhauer, A. O mundo como vontade e representação, p. 510 .

18. Cf. Idem, ibidem.

19. Cf. Schopenhauer, A. O mundo como vontade e representação, E, cap. 48. In: . Sämtliche Werke.vol. III, p. 700. Isso não nos deve levar a ver a negação da vontade como uma reabsorção do indivíduo no todo do mundo, como se bastasse restabelecer a unidade que a multiplicidade do mundo fenomênico desfez para alcançar a redenção. Essa interpretação, porém, está presente em uma série de comentadores da obra de Schopenhauer, e mesmo Horkheimer parece interpretá-lo assim num texto dos Notizen (que permaneceu póstumo) intitulado "Schopenhauer als Optimist". Segundo Horkheimer, mesmo Schopenhauer, com a teoria da negação da 
Schopenhauer, Adão simbolizaria a natureza e a afirmação da vontade, e Cristo a graça, a negação da vontade, a redenção:

Decididamente, a doutrina do pecado original (afirmação da vontade) e da redenção (negação da vontade) é a grande verdade que forma, por assim dizer, o núcleo do cristianismo; todo o resto é, a maior parte das vezes, apenas vestimentas e invólucro, ou algo acessório. ${ }^{20}$

A partir desse ponto podemos destacar o que seria a "filosofia da religião" de Schopenhauer, ressalvando-se o fato de o filósofo indicar sua desconfiança com relação a essa expressão que remete a Hegel, notando, entretanto, uma certa semelhança entre os

vontade de viver, recairia no dogmatismo otimista ao considerar a possibilidade do fim do sofrimento como uma realidade metafísica. Para ele, ainda que Schopenhauer não argumente contra a realidade da miséria, como fazem os outros sistemas, ainda assim ele incorreria no erro de considerar possível uma reconciliação da vontade consigo mesma. Esta se daria com o retorno da vontade individual à vontade una: "no fundo, [ele] pensa que a dor e o tédio só correspondem à vontade individual, não à vontade lisa e plana". Disso se segue, para Horkheimer, que Schopenhauer expressaria um otimismo metafísico ainda mais decisivo ao aceitar o mito da transmigração das almas, que estaria pressuposto na idéia de que apenas alguns indivíduos podem alcançar uma saída redentora do mundo como vontade. Assim, conclui Horkheimer, "a boa infinitude é um consolo duvidosamente filosófico. Dessa maneira, em última instância, Schopenhauer conserva a razão contra si mesmo. O quarto livro de sua obra principal se revela como um descarrilamento, como um lapsus que os outros três conseguem refutar". Horkheimer, M. Notizen. In: . Gesammelte Werke, vol. 6, p. 388. Já na conferência Pessimismus Heute (1969), essa mesma interpretação de Schopenhauer é o ponto de partida para vincular o pessimismo teórico com uma "práxis não não-otimista" (nicht unoptmistische Praxis), pois representaria uma via de superação do pessimismo por meio de uma solidariedade que contém em si momentos teológicos. Essa interpretação, porém, nos parece questionável, pois Schopenhauer não fala em nenhum momento de um retorno, a não ser o retorno ao estado anterior ao delito do nascimento, o que só pode ser caracterizado negativamente como "nada". O inteiramente outro, em Schopenhauer, se apresenta como algo simplesmente inteiramente diferente do mundo fenômenico. Cf. Schopenhauer, A. O mundo como vontade e representação. Complementos, Cap. 48. In: Sämtliche Werke, vol. III, p. 691.

20. Schopenhauer, A. O mundo como vontade e representação, § 70. In: Sämtliche Werk, vol. II, p. 480. 
dois filósofos no que diz respeito à fronteira entre a filosofia e a religião. Para Schopenhauer, o conhecimento metafísico expresso nas religiões sempre apresenta um conteúdo profundo de verdade, mas quase sempre envolto numa linguagem alegórica, simbólica. Nesse sentido, ele diferencia a verdade sensu proprio da metafísica racional da verdade sensu allegorico das religiões. A religião apresenta assim a verdade "sob a roupagem da mentira" e,

quando se compreende a dogmática cristã sensu próprio, então tem razão Voltaire, mas tomada em sentido alegórico ela é um mito sagrado, um veículo pelo qual são trazidas ao povo verdades que de outro modo the seriam inacessíveis. ${ }^{21}$

Portanto, é por meio de uma certa aproximação do cristianismo com o budismo e o hinduísmo, e da acentuação do caráter ascético do cristianismo como uma rejeição religiosa da existência mundana, que Schopenhauer procura salvar o conteúdo da fé cristã. A justificação da moral cristã ocorre por meio de tal rejeição e a vida dos santos serve como modelo não por causa dos dogmas religiosos, mas pela visão daquilo que há de mais íntimo no universo que estaria na base de suas ações. O mundo dos fenômenos, a realidade da experiência sensível, não é a obra de uma potência divina, a expressão de um ser bom em si mesmo e eterno, mas da vontade que se afirma identicamente em cada ser finito, e é por isso que cada um pode se identificar com cada um não por meio de motivos particulares, mas por sua experiência comum na vivência do sofrimento. Por isso, conclui Horkheimer, "quem reconhece

21. Schopenhauer, A. Parerga e Paralipomena, § 177. In:__. Sämtliche Werk, vol. VI, p. 394. Na conferência Religião e Filosofia, Horkheimer aponta a concordância dessa concepção de Schopenhauer com o pensamento do teólogo protestante Paul Tillich. A semelhança com Hegel estaria na consideração do momento de verdade da religião pelo qual um conteúdo verdadeiro estaria expresso na forma inadequada da alegoria ou da representação. Cf. Schmidt, A. Die Wabrheit im Gewande der Lüge - Schopenhauers Religionsphilosophie. München, Zürich: Piper, 1986. 
sua obra como verdadeira não afirma de maneira alguma os dogmas, mas certamente o espírito do evangelho". ${ }^{22}$

A partir dessa recepção de Schopenhauer, Horkheimer irá desenvolver, em seus últimos escritos, uma recuperação da teologia que, em parte, se inspira no pensamento do autor do Mundo como Vontade e Representação e, por outro lado, dele se afasta. $\mathrm{O}$ autor transforma positivamente o anseio pelo inteiramente outro, que em Schopenhauer tinha apenas um caráter negativo, numa esperança efetiva de que o mal do mundo não seja a última palavra da realidade. É verdade, porém, que essa esperança permanece um sentimento com sentido prático e jamais dá lugar a um conhecimento efetivo. Nesse sentido, o pensamento de Schopenhauer, apesar de marcado pelo pessimismo, constitui um consolo positivo, pois ainda representa a tentativa de buscar um significado moral do mundo para além do positivismo e em contraste com a completa socialização levada a cabo pela sociedade totalmente administrada. Sua teoria, apesar de antecipar e justificar o pessimismo dos dias de hoje, "não é, de modo algum, tão pessimista quanto a absolutização da ciência". ${ }^{23}$ Ela pode "fundar uma solidariedade que, de maneira não dogmática, contém em si momentos teológicos" ${ }^{24}$, pois o "pessimismo une experiências histórico-filosóficas com a herança da grande teologia. Sua difusão poderia ocasionar muito mais o bem do que a formação cada vez mais, e em toda parte, exclusivamente profissional". ${ }^{25}$

\section{BIBLIOGRAFIA:}

CHIARELLO, M. G. Das Lágrimas das coisas. Estudo sobre o conceito de natureza em Max Horkheimer. Campinas: Editora da Unicamp, 2001.

22. Horkheimer, M. Religion und Philosophie. In: Gesammelte Schriften, vol. 7, p. 193.

23. Horkheimer, M. Schopenhauers Denken im Verbältnis zu Wissenschaft und Religion. In:__. Gesammelte Schriften, vol. 7 (Voträge und Aufzeichnungen 1949-1973), pp. 252.

24. Horkheimer, M. Pessimismus Heute. In: Gesammelte Schriften, vol 7, p. 232. O texto continua: "Com sua postura no final negativa vincula-se àquilo que aqui em Frankfurt é conhecido como 'teoria crítica”.

25. Idem, Ibidem. 
HORKHEIMER, M. "La actualidad de Schopenhauer”. In: ADORNO, T.W.; . Sociologica, Madrid: Taurus, 1966.

"Schopenhauer y la Sociedad". In: ADORNO, T. W.; Sociologica, Madrid: Taurus, 1966.

. Voträge und Aufzeichnungen 1949-1973. In: Gesammelte Scbriften. vol. 7. Org. de A. Schmidt. Frankfurt: Fischer Taschenbuch Verlag, 1985.

. Eclipse da Razão. Trad. de Sebastião Uchoa Leite. São Paulo: Centauro, 2001.

- Teoria Crítica I. Trad. de Hilde Cohn. São Paulo: Perspectiva, 2006.

POST, W. Kritische Theorie und metaphysischer Pessimismus. Zum Spätwerk Max Horkheimers. München: Kösel-Verlag, 1971.

SCHMIDT, A. Drei Studien über Materialismus. Schopenhauer, Horkheimer, Glücksproblem. Munique: Carl Hanser Verlag, 1977.

_. Die Wabrheit im Gewande der Lüge - Schopenhauers Religionsphilosophie. München, Zürich: Piper, 1986.

. Max Horkheimer heute: Werk und Wirkung. Frankfurt am Main: Fischer, 1986.

SCHOPENHAUER, A. Sämtliche Werke. Editadas e comentadas criticamente por Arthur Hübscher. Wiesbaden: F. A. Brockhaus, 1972. . Parerga e Paralipomena. Trad. de Wolfgang Leo Maar. In: Coleção "Os Pensadores", São Paulo: Abril Cultural, 1980. . O mundo como vontade e representação. Trad. de Jair Barboza. São Paulo: Unesp, 2005.

VEAUTHIER, F. W. "Zur Transformation der Pessimismus-Motive im Denken Max Horkheimers". In: Schopenhauer Jabrbuch, no 73, Frankfurt am Main, 1988, pp. 593-607. 


\title{
O pensamento de Schopenhauer em relação à ciência e à religião*
}

\author{
Max Horkheimer
}

$\mathrm{Na}$ história da filosofia moderna a obra de Schopenhauer é tida como modelo do pessimismo: “... quem permaneceria na vida, como ela é, se a morte fosse menos aterrorizante? - E quem poderia sequer suportar o pensamento da morte se a vida fosse um júbilo! Mas ela tem ainda o lado bom de ser o fim da vida, e nós nos consolamos dos sofrimentos da vida com a morte, e da morte com os sofrimentos da vida. A verdade é que as duas estão inseparavelmente ligadas, pois constituem um labirinto do qual é tão difícil quanto desejável escapar", ${ }^{1}$ é dito no segundo volume de sua obra principal, e ele cita Voltaire: "le bonheur n'est qu'un rève, et la douleur est réelle". ${ }^{2}$ Ele esclarece "que ainda que milhares tivessem vivido na felicidade e na volúpia, a angústia e a agonia mortal de um só indivíduo não seriam suprimidas; e tampouco meu bem-estar presente desfaz meus sofrimentos passados". ${ }^{3} \mathrm{O}$ cristianismo, com o qual ele se pretende continuamente de acordo, "pois... no evangelho mundo e mal são usados quase como sinônimos”, teria pelo menos até o século dezoito, e mesmo no presente, acrescentado não só o pensamento do céu e do inferno, mas muito mais ao destino individual no além. Mesmo as vítimas cristãs do sadismo romano, como relata o historiador Harnack, consideravam a própria morte sob tortura na arena como um caminho cur-

* O texto dessa conferência se encontra em Horkheimer, M. "Schopenhauers Denken im Verhältnis zu Wissenschaft und Religion”.In:__. Gesammelte Schriften. Org. de Alfred Schmidt e Gunzelin Schmid Noerr. Frankfurt: Fischer Taschenbuch Verlag, 1985, vol. 7: Voträge und Aufzeichnungen 1949-1973, pp. 240-52. O tradutor agradece as sugestões e correções de Fernando Costa Mattos.

1. Schopenhauer, A. Sämtliche Werke. vol. II. Leipzig: Grisebach, pp. 677 e ss.

2. Em francês no original: "a felicidade é apenas um sonho e a dor é real" (N. do T.).

3. Idem, p. 678. 
to, ainda que doloroso, para a beatitude eterna. A vida de homens verdadeiramente religiosos, que tinham a consciência atravessada pela própria culpa, possuía um sentido que hoje é questionado. Mesmo a interpretação psicológica de Schopenhauer é duvidosa. $\mathrm{O}$ consolo da própria morte não provém somente do sofrimento na vida, assim como o consolo do sofrimento não provém somente da morte, como se sem ela a felicidade tivesse também de ser definitivamente excluída. Mais duvidosa ainda é a metafísica, quer ela indique o além, o em-si, como um positivo - o bem -, quer ela o indique como um negativo - o mal [Schlechte] e o nada. $\mathrm{O}$ pensamento humano pode ordenar os fatos da percepção, mas não pode ir além deles, mesmo que seja o anseio de origem teológica por um outro mundo que não este. $O$ conceito de seres superiores, seja no singular ou no plural, não é mais subjetivo do que o conceito do Nada.

Até a renascença, e para muitos grupos sociais ainda até o século dezenove, o Deus todo-poderoso e infinitamente bom, bem como a obrigatoriedade de seus mandamentos, não eram menos certos e realistas do que as teorias físicas e químicas o são hoje. Quem negava a criação do mundo de acordo com a bíblia não passava apenas por herético, mas por mentalmente deficiente. A idéia da vida neste mundo incluía o pensamento do além. Proválo, desde que a religião se viu ameaçada pela ciência, formou tanto psíquica quanto socialmente um motivo fundamental para fomentar a filosofia na civilização ocidental. A administração [da vida] ainda não é tão ampla como será no futuro, caso catástrofes não retardem o processo. A filosofia cumpriu continuamente, nos tempos modernos, a função social de conciliar com o progresso técnico-científico, por meio de provas da existência de Deus, o pensamento da recompensa e do castigo depois da morte, e com isso o impulso interior para a ação socialmente necessária. A tarefa se tornou cada vez mais difícil, e por fim insolúvel. Já a perspicaz reflexão de Descartes é interrompida pelo recurso ao argumento da existência de Deus. Ele diz que, se não houvesse nenhum ser perfeito e supremo que correspondesse à viva representação em mim, então ela não poderia estar em meu espírito, já que a causa nunca é inferior ao efeito. Para ele, opostamente a Kant, a exis- 
tência pertence à perfeição. Que eu possa pensar em Deus seria garantido pela certeza de sua existência. A precariedade das demonstrações em favor do teísmo, mesmo nos grandes pensadores filosóficos, tornou-se regra nos séculos seguintes. John Locke, o pai do empiriocriticismo, retorna à prova cosmológica. Leibniz, o racionalista, esclarece a idéia de um ser supremo como imanente à razão, assim como as leis lógicas, sem cuja observação a verdadeira reflexão [Besinnung] não é possível. Mesmo Kant, o genial crítico das habituais provas da existência de Deus, não constitui exceção. A partir do imperativo categórico é postulada a certeza em um ser supremo, ao passo que, tendo em vista o horror no passado e no presente, a afirmação de que cada sujeito humano tem o respeito ao próximo como uma lei interior não parece menos improvável do que as doutrinas monoteístas do Eterno.

Se na filosofia como na religião a convicção na efetividade da justiça celeste garante uma disposição no fundo otimista, então Schopenhauer, apesar de seu ateísmo, não era meramente pessimista. Ele vincula à teologia cristã, além da tese comum da terra como um vale de lágrimas, também a idéia de um destino justo da alma individual para além da morte. $O$ renascimento para a existência sofredora, assim como, por outro lado, o retorno à unidade absoluta, seriam proporcionais, segundo seu ensinamento, à substância moral do indivíduo, à sua medida em compaixão e simpatia [Mitfreude], ou a seu ódio nessa vida. Tal promessa correspondia, de um modo novo, mais racional, à necessidade pela justiça eterna, cujo crescente descrédito, cuja negação mesma no presente, condicionam inconscientemente o mal-estar da nova como da vetha geração. Sofrimento inocente, triunfo do mal, todo horror de milênios não são recompensados, assim, em nenhuma eternidade. Possam revolta e satisfação, e mesmo o conceito de justo e injusto, como reação a acontecimentos historicamente herdados, serem incorporados por meio do desenvolvimento psicológico e social, a representação do caráter definitivo de um acontecimento terreno contradiz o homem do presente que ainda se sente convicto.

Com todo respeito pela ciência, instrumento tanto da atividade prática quanto da intelectual, trata-se de preservar o pensamento de um transcendente, de um incondicionado, não como 
dogma, mas como um motivo espiritual que une os homens. Pertence aos momentos culturais ainda não inteiramente esgotados, mas que são, porém, os mais ameaçados. A dissolução da família, o declínio da verdadeira autoridade, e ainda o descuido com reformas há muito necessárias nos cursos escolares e universitários, são apenas algumas das razões que se contrapõem ao desenvolvimento do indivíduo. A problemática já era conhecida por Schopenhauer. Embora a certeza em um positivamente absoluto, divino, the aparecesse com razão como problemática, ele explicou pormenorizadamente a dinâmica sócio-psicológica de credos religiosos e seculares. Que se pense na relação entre religião e fidelidade à pátria. Desde que o amor ao próprio povo não se transforme em nacionalismo, mau patriotismo, em ódio contra outros grupos, ele cumpre, segundo Schopenhauer, uma função ética, metafisicamente fundada. A nação leva o indivíduo a sobreviver, e até a suprimir de certo modo sua herança; ele tem tanto em comum com seus concidadãos - linguagem, usos, orgulho e complexo de inferioridade conforme o destino da coletividade -, que forma instintivamente com eles, em meio a todas as diferenças, uma unidade. "Quem morre pela pátria", diz-se no ensaio Sobre o Fundamento da Moral, "está livre da ilusão que limita a existência à própria pessoa. Ele expande seu próprio ser a seus compatriotas, nos quais ele continua a viver, e à geração vindoura deles, para a qual ele atua. Então considera a morte como o piscar de olhos que não interrompe a visão". ${ }^{4}$ Se uma tal disposição não fosse determinante para os judeus há séculos, então eles não teriam sobrevivido como povo. Há passagens na bíblia que estão dirigidas ao mesmo tempo ao povo e aos indivíduos; a diferença é suprimida. Que se pense no mandamento do amor ao próximo: "e quando encontrares um estrangeiro em vossa terra, vós não deveis oprimilo. Seja o estrangeiro que vós encontrastes como o nativo entre vós, e vós deveis amá-lo como a vós mesmos". ${ }^{5}$ Que o indivíduo se identifique incondicionalmente com seu povo, que esteja convicto

4. Schopenhauer, A. Sämtliche Werke, vol. III, p. 654. Edição brasileira: Sobre o fundamento da moral. Trad. de Maria Lúcia Cacciola. São Paulo: Martins Fontes, 1995, p. 210.

5. Terceiro livro de “Moisés”, Cap. 19, Vers. 33-34. 
de sua conservação nele depois da própria morte, tudo isso me parece uma razão pela qual a eternidade da alma, como individual, não virou objeto de nenhuma crença no Judaísmo.

A relação do pessimismo de Schopenhauer com o positivismo - a absolutização filosófica da ciência, a identificação dos conhecimentos desta com a verdade pura e simples - é difícil de determinar, por mais que ele mesmo enfatize a diferença. Dos conhecimentos naturais científicos, assim como de sua própria filosofia, segue-se a nulidade humana. "Inumeráveis esferas brilhantes no espaço infinito, e ao redor delas mais uma dúzia de espécies menores e esclarecidas, quentes em seu interior mas frias e solidificadas em sua superfície, em que se criaram diversos seres vivos e inteligentes; - esta é a verdade empírica, o real, o mundo". Assim começa o segundo volume da obra principal de Schopenhauer. Por mais que a ciência dê hoje um tratamento diferente a essa tese, ambas concordam no essencial. Para Schopenhauer, entretanto, ela é um mero juízo empírico sobre o mundo do fenômeno, sobre a relação do homem com o universo, não sobre a substância metafísica. Mesmo assim, sua doutrina da ciência está mais próxima da realidade do que a interpretação religiosa; pois a origem fundamental do mundo não é para ele nenhum Deus bondoso, e sim a insensata Vontade, o impulso latente para a existência e a vida; os investigadores empíricos desconhecem um fundamento originário, mas reconhecem um ímpeto no homem e no animal que - com exceção da escola freudiana -constitui ainda um assunto muito raro. Mas a atualidade de sua obra não repousa apenas nessa relação interna com a ciência avançada. Elementos importantes de sua metafísica, como a vontade de viver no homem individual, poderiam ser psicologicamente interpretados como libido; em todo caso, as ciências lhe parecem mais significativas que as religiões, ainda que estas sejam "necessária ao povo... e... um bem inestimável". ${ }^{6}$ Ele afirma o pensamento de Epicuro segundo o qual a morte não nos atinge, pois "quando nós somos, a morte não é, e, da mesma forma, quando a morte é, nós não somos". ${ }^{7}$ O medo da

6. Schopenhauer, A. Sämtliche Werke, vol.II, p. 194.

7. Idem, p. 548. 
morte derivaria somente da cega vontade de viver; não dependeria da duração da própria existência, mas da manutenção autêntica das gerações futuras. "O fim último de todo caso amoroso... é de fato mais importante que toda outra finalidade da vida humana", ele diz respeito, em sua diferenciação [Differenziertheit], em sua determinidade específica em cada caso particular, "ao estabelecimento da próxima geração". ${ }^{9} \mathrm{O}$ patriotismo, em especial quando quer fazer-se valer no domínio da ciência, permanece precário apesar de sua proximidade, considerada positiva, em relação à religião, "pois o que pode ser mais impertinente do que querer dar importância ao seu amor pela nação, ao qual pertence o valor da própria pessoa, justamente ali onde se trata do humano puro e geral, e onde somente a verdade, a clareza e a beleza têm valor". ${ }^{10}$

Schopenhauer se coloca criticamente contra pensamentos e emoções que entram em conflito com aquilo que é faticamente verificável, desde que não se trate da má Vontade de viver ou do único além metafísico justificável, o nada. Não menos do que Marx conheceu e condenou ele a miséria do proletariado de então, sem proclamar, é claro, a problemática utopia do livre desenvolvimento das forças produtivas como condição última. "Como o homem se relaciona com o homem mostra-se, por exemplo, na escravidão dos negros, ... Mas não é necessário ir tão longe: entrar numa tecelagem, ou qualquer outra fábrica, na idade de cinco anos, e lá permanecer diariamente por 10, depois 12 e finalmente 14 horas, e executar o mesmo trabalho mecânico: eis o que é pagar caro pelo prazer de respirar. Este é, entretanto, o destino de milhões, e análogo a ele é o de muitos outros milhões". ${ }^{11} \mathrm{~A}$ necessidade do Estado repousa, segundo Marx, na injustiça social. Trata-se de tornar a sociedade mais justa e mais pacífica. No fim das contas, o indivíduo torna-se na realidade tão nulo como Schopenhauer o interpretou. $\mathrm{O}$ futuro pertence ao coletivo, fim último da espécie. Também ele é apenas, de fato, um fenômeno da vontade de viver, a

8. Idem, p. 627.

9. Idem, ibidem.

10. Schopenhauer, A. Sämtliche Werke, vol.V, p. 516.

11. Schopenhauer, A. Sämtliche Werke, vol. II, p. 680 e ss. 
perpetuação ilimitada de um passo em falso. Indivíduos são meios, povos são estádios intermediários e transitórios da história da espécie. O que se dá no período presente - o declínio do significado social do indivíduo, sua crescente substituibilidade [Ersetzbarkeit] - é conseqüente segundo a filosofia de Schopenhauer. Em todo caso, confirma-se com isso a doutrina da absurdidade do medo da morte, da vaidade da existência do ego humano. A crescente automatização, temida e denunciada por aqueles ainda ligados à cultura, mostra-se como progresso não apenas histórico, mas necessário; a organização racional, até mesmo a igualdade, propagam-se de maneira modesta. Mesmo que Schopenhauer não se tenha expressado sobre isso, a constituição da humanidade como a mais alta, mais refinada espécie animal - em contraste com as ilusões teístas, utópicas e outras de um futuro parasidíaco -, corresponde inteiramente à sua filosofia. A alternativa significa ou liberdade e opressão, ou justiça e mundo totalmente administrado. Liberdade e desenvolvimento das forças estão necessariamente ligadas à opressão pelos mais fortes. A igualdade, porém, liga-se ao declínio da inteligência que uma sociedade da igualdade torna possível. A aproximação de todas as funções aparece como a razoável, necessária e ao mesmo tempo precária finalidade da raça humana.

A doutrina de Schopenhauer vai ao encontro da ciência. Não por acaso, Freud se refere recorrentemente "às amplas concordâncias da psicanálise com a filosofia de Schopenhauer" ${ }^{12}$ Emoções profundas, fidelidade aos mortos, até o amor passional, que forma o motivo das grandes tragédias, não menos do que o ódio, tornamse objeto de terapia na análise. "A superestimação sexual", especialmente característica do gênero masculino, "ocasiona o surgimento da autêntica condição da paixão, que lembra a coerção neurótica e conduz a um empobrecimento da libido do ego em favor do objeto". ${ }^{13}$ Do luto diz Freud: "Nós vemos agora que a libido se agarra a seu objeto e dele não desiste, mesmo quando se perdeu e o sucedâ-

12. Freud, S. Ges. Schriften. vol. XI. Wien: 1928, p. 172.

13. Freud, S. Ges. Schriften. vol. VI. Wien: 1925 , p. 171 e ss. 
neo já está presente". ${ }^{14} \mathrm{E}$ assim poderíamos prosseguir, se a força para a atividade racional não se extinguiu. Afligir-se de modo demasiadamente profundo, e por um tempo demasiadamente longo, é considerado por Freud tão incorreto como outras posturas nãopragmáticas. "O luto pesado", diz ele na Metapsicologia, "a reação à perda de uma pessoa amada inclui... a perda da capacidade de escolher qualquer outro objeto de amor - que poderia substituir aquele cuja perda se lamenta -, o afastamento de todo esforço que não se relacione com a lembrança do falecido... De fato, um tal comportamento não nos parece patológico, pois sabemos esclarecê-lo muito bem". ${ }^{15}$ Desde então, o analisado bem sucedido se torna positivista, pratica a razão instrumental. Nem a perda de uma pessoa amada, nem a perda de uma guerra devem influenciar decisivamente a própria vida. A advertência providencial de Schopenhauer sobre a necessidade do acontecimento, assim como de tudo que nos afete de modo ainda pior, aproxima-se mais do modo de pensar sóbrio e científico do que do metafísico, da esperança no absoluto que ele mesmo queria restringir à renúncia da vontade de viver, à "completa calmaria oceânica de espírito". Ele estimou aquela profunda calma - de meros "reflexos no rosto, como expostos por Rafael e Corregio" -, enquanto "confiança inabalável e serenidade, ... um completo e seguro evangelho". ${ }^{16}$ À medida que o curso atual da sociedade tende a abolir a fé religiosa, os pensamentos de Schopenhauer não são mais pessimistas do que o conhecimento que se limita à pesquisa exata. Ao contrário, a negação da vontade, a "paz que é maior do que toda razão" ${ }^{17}$, e que em Schopenhauer, ainda que preenchível apenas pelo não ser, é ao menos uma esperança conservada na redenção, corre o risco, como resto de idealismo, como romantismo, de andar de mão dadas com a teologia. O mundo é visto então não mais como fenômeno, que com todos os seus horrores deixa ao menos em aberto a idéia de um outro mundo, de um além, mas exclusivamente como estrutu-

14. Freud, S. Ges. Schriften, vol. XI, p. 293.

15. Freud, S. Ges. Schriften. vol. V. Wien: 1924, p. 536.

16. Freud, S. Ges. Schriften. vol. I. Wien: 1924, p. 526.

17. Idem, ibidem. 
ra de fatos, como a única e verdadeira realidade reconhecida pelo pensamento sadio.

A teoria pessimista era insuportável tanto para aqueles aos quais a vida, a terra e o mundo, apesar de toda dificuldade e de toda miséria, pareciam também, no entanto, realizar o bem, quanto para aqueles que confiavam em tal possibilidade, senão para esta, pelo menos para outra região além. A eles pertenciam não apenas os teólogos, mas também grandes filósofos, de Platão e Aristóteles até Immanuel Kant, e mesmo Bertrand Russel e outros positivistas do presente. Não são poucos os que divergem disso, como, por exemplo, o científica e diplomaticamente ativo Gottfried Wilhelm Leibniz, não injustamente considerado otimista. Tanto teórica como praticamente, procurou ele atuar, para si e para outros, para a Alemanha e para a Europa, para a ciência e para a filosofia, como um homem de ação. Ele foi o modelo de um homem engajado e progressista. Façamos uma imagem mais obscura do núcleo de uma doutrina, porém, do que a afirmação, própria a Leibniz, de que o mundo cruel que conhecemos é "o melhor de todos os mundos possíveis"! O princípio do pensamento pessimista, a convicção de que o nada é melhor do que algo, constitui o oposto desse modo de pensar. $\mathrm{O}$ conceito de nada, ao menos como ideal, necessitaria de uma análise que, em sua complexidade, não fica atrás da determinação do absoluto, do inteligível nas palavras de Kant. O nada, que o espírito não mais dominado pela vontade de vida gostaria de adentrar, pode ser - como dito acima - um conceito do sujeito tanto quanto o algo. Ainda que de modo negativo e ligado ao fenômeno, o nada constitui ainda uma representação humana, do mesmo modo como o aquém ou o além, o céu, a beatitude. Mesmo com toda a negação, a idéia metafísica de Schopenhauer não está meramente contraposta à idéia religiosa; ela exige do homem a liberdade em relação ao egoísmo, a entrega, a confiança em algo não passível de comprovação no mundo, em algo não mais ou ainda não existente. Todavia, a caracterização do além como vontade universal ${ }^{18}$ é, ainda que justificada, uma trans-

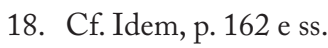


gressão da proibição, afirmada e transgredida pelo próprio Kant, de extraviar-se no reino do inteligível. Schopenhauer apagou o brilho da esperança, mantida viva pela teoria agnóstica de Kant - segundo a qual o mundo da experiência seria mero fenômeno -, na medida em que transpôs a nulidade do indivíduo para o transcendente.

A obra do filósofo Schopenhauer não está ultrapassada. Ele afirma a ciência como único conhecimento confiável. Todo positivo para além dos fenômenos é negado, exceção feita à assim chamada transmigração das almas, "a crença na metempsicose, na palingenesia" ${ }^{19}$, quer dizer, a representação da "sucessão dos sonhos da vida de uma Vontade em si indestrutível”, que no final, através do "conhecimento, é ensinada e melhorada em uma forma sempre nova, até suprimir a si mesma". ${ }^{20} \mathrm{~A}$ vontade, o "lugar dos desejos e paixões", que é essencial ao indivíduo, é considerada como a má essência [Wesenhafte]. A questão que se coloca é a de saber como pensar, em uma tal metafísica, o destino duradouro que cabe a seu portador. O corpo é dominado pela vontade de viver e não pela alma, cujo conceito, segundo Schopenhauer, deve ser entendido em sentido "trópico", figurado. Quando ela se separa da consciência na morte, então sua sobrevida, neste ou em outro planeta, constitui, para o perplexo indivíduo, um acontecimento estranho do ponto de vista de sua efetivação. $\mathrm{O}$ processo pode se referir exclusivamente ao inconsciente, que Schopenhauer, já antes de Freud, considerou como um momento decisivo na vida individual. Por mais que também em sua doutrina a precária ressurreição se aproxime do pensamento cristão do céu e do inferno, da justiça supraterrena, o respectivo sujeito cognoscente vivencia o destino da vontade individual a ele ligada, antes do nascimento e depois da morte, tão pouco quanto as particularidades da existência de um ser que não conheça em outra via-láctea do universo. Também segundo o tão combatido Hegel, "a morte é o lado da cisão em que o o ser-para-si alcançado" - portanto o futuro si mesmo -, "é um

19. Cf. Schopenhauer, A. Sämtliche Werke, vol. II, p. 590.

20. Idem, p. 591. 
outro que o essente [Seyende] que iniciou o movimento". ${ }^{21}$ Com sua tese do renascimento no mundo ruim ou ingresso no nada, o autor do Mundo como Vontade e Representação deu prosseguimento à tentativa da filosofia moderna de unir a idéia da justiça transcendente, assim como outras idéias religiosas, ao reconhecimento irrestrito da ciência. $\mathrm{O}$ eu, que antes devia sobreviver à sua existência terrena em função do prêmio ou punição no além, decompõe-se ao morrer, torna-se efêmero. Já durante a vida "o ponto obscuro na consciência" ${ }^{22}$, tem ele de perecer completamente com o corpo.

Em vista da perda de significado social do indivíduo, o juízo de Schopenhauer sobre o eu está de acordo com as tendências sociais do presente. Que ele considere como essencial para a alma não o eu, mas a vontade de viver que caracteriza tanto o homem quanto o animal, constitui um elemento fundamental de sua filosofia pessimista. Mesmo as qualidades espirituais, pelas quais o homem excede o animal, são fenômenos de transição. Nisso se incluem esferas culturais como a religião, o respeito à grande tradição, a filosofia: que elas percam sua função na sociedade administrada do futuro, e apesar de toda distinção apareçam como infantis, já se percebe hoje por sua transformação. A apressada liberalização da teologia, a passagem do estético ao abstrato, a compreensão da filosofia como disciplina antiquada da ciência, são sintomas de tal desenvolvimento. Tudo o que não é fundado em fins realistas, egoístas ou altruístas, aparece sempre como ingenuidade. Emoções carentes de motivos pragmáticos são tidas por sentimentais; para a grande psicologia, como já dito, por doentias. A fidelidade aos mortos, própria também a muitos animais, existiria graças ao instinto ou à superstição. Apesar de partir do ritmo social, da cada vez mais forte ligação com a cultura do especialista, do reconhecimento dos limites entre o conhecimento exato e as crenças plausíveis - que pelo menos desde a Reforma é levado em conta -, a

21. Hegel, G. W. F. Phänomenologie des Geistes. In: Sämtliche Werke (Jubiläumsausgabe). vol. 2. Stuttgart: 1927. Edição brasileira: Hegel, G. W. F. Fenomenologia do espírito. Trad. de Paulo Menezes. Petrópolis: Vozes, 2001, vol. II, p. 14.

22. Schopenhauer, A. Sämtliche Werke, vol. II, cap. 41. 
ciência não parece admitir que, segundo seus próprios princípios, a crença monoteísta não é mais razoável que a crença no politeísmo, na bruxaria, no satanismo ou em qualquer tipo de ilusão. $\mathrm{O}$ caminho da humanidade rumo à espécie mais refinada do planeta prossegue. $\mathrm{O}$ futuro desenvolvimento da razão corresponde ao desenvolvimento da ciência. Viver com tal crença, que nega a idéia do além, está de acordo com a época mas, ao mesmo tempo, é difícil para o pensador - a menos que ele faça do nada, com efeito, a sua esperança metafísica. Frente à estatística, a existência individual parece cada vez mais irrelevante. A injustiça no passado e no presente, a morte dos martirizados, o prazer do criminoso, permanecem a última palavra para aqueles a que dizem respeito, ao menos para a pessoa [das Ich] das vítimas.

Todas as teorias que pensaram poder determinar um ser ordenador do mundo já se tornaram históricas. A existência de um deus todo-poderoso e de infinita bondade, na qual tanto teólogos como muitos dos grandes iluministas acreditavam, não é, de fato, tão bem fundamentada como o espírito absoluto, a vontade universal ou o nada. Como quer que se apresente o incondicionado positivo ou negativo, o transcendente em relação ao mundo do fenômeno, ele sempre contradiz a visão segundo a qual toda realidade reconhecida pelo entendimento deve-se amplamente às funções intelectuais do sujeito e, por isso, deve ser concebida também como momento do fenômeno. Quanto maior o progresso, tanto mais se vê ameaçada não apenas a fé, mas o verdadeiro anseio pelo outro. Todo pensamento e sentimento não puramente positivista aparece cada vez mais como fenômeno do período infantil da humanidade, o qual, não menos do que o do indivíduo, deve ser hoje decididamente reduzido. A velhice e a infância aparecem como negativas frente ao frescor do jovem adulto. Consciente ou inconscientemente, ele experimenta tudo o que não é estritamente fático, que não é faticamente comprovável, assim como o pensamento que não seja de antemão direcionado a algum fim prático, como pura especulação. Também a filosofia de Schopenhauer, na medida em que ultrapassa o positivismo, sua doutrina sobre o significado metafísico, sobre o sentido objetivo da compaixão e da simpatia (Mitfreude) que aponta para o transcendente, não é menos questionável, para o intelectual médio, do que a crença no Deus-pai e 
em todos os conceitos a ele ligados. Costumes religiosos servem à maioria da população apenas como racionalização dos feriados, em algumas circunstâncias como pretexto para relações pessoais. O curso presente da sociedade é uma justificação do pessimismo que Schopenhauer pressentia, mas ainda não era capaz de analisar. A alma humana se desenvolve em direção a uma função automatizada, próxima à do computador. Nenhuma emoção conta ainda se não for enquadrada na realidade apreendida pela ciência. Quanto mais o pensamento humano tenha de reduzir-se decididamente à atividade puramente instrumental, tanto mais a comprovação de cultura corresponderá com precisão à convicção de Schopenhauer de que "a nossa condição é ao mesmo tempo extremamente miserável e pecaminosa" ${ }^{23}$ - mesmo quando, poder-se-ia acrescentar, a igualdade da humanidade funcionando como espécie, depois das épocas bárbaras do passado, devia expandir-se.

A teoria pessimista de Schopenhauer é um consolo. Em contraste com a mentalidade atual, sua metafísica oferece a mais profunda fundamentação da moral, sem entrar em contradição com o conhecimento científico e, sobretudo, sem recorrer à representação de espíritos sobrenaturais, eternos, bons ou maus. Com a idéia da morte vincula-se não apenas a certeza no desaparecimento do eu, determinada por ela, mas também a preocupação, em um intervalo que não pode ser previsto - o tempo é subjetivo -, com o instinto imperecível de voltar à vida enquanto ser vivo, planta, animal microscopicamente pequeno ou grande, seja na Terra ou em outro astro qualquer. Tal noção aponta simplesmente para a identidade do vivo e consegue fundar a solidariedade com todas as criaturas bem antes da morte. Cada um se identifica até com o mais precário ser. A teoria da identidade da vontade está hoje mais próxima daquele que medita seriamente do que os argumentos ligados a dogmas tradicionais da filosofia moderna. Esta queria conciliar religião e ciência, oferecer provas rígidas para a existência do criador extraterreno, sem colocar em questão os mandamentos religiosos, socialmente condicionados, das conviç̧ões religiosas. Schopenhauer fundamentou filosoficamente o amor ao próximo, à criatura em geral, sem sequer tocar nas hoje questioná-

23. Idem, p. 197. 
veis afirmações e prescrições das religiões. Seu pensamento não é, de modo algum, tão pessimista quanto a absolutização da ciência.

\section{Tradução de \\ Flamarion Caldeira Ramos}

\section{BIBLIOGRAFIA:}

FREUD, S. Ges. Schriften. vol. I. Wien: 1924.

. Ges. Schriften. vol. V. Wien: 1924.

. Ges. Schriften. vol. VI. Wien: 1925.

Ges. Schriften. vol. XI. Wien: 1928.

HEGEL, G. W. F. Phänomenologie des Geistes. In:

(Jubiläumsausgabe). vol. 2. Stuttgart: 1927. . Sämtliche Werke

Fenomenologia do espírito. 2 vols. Trad. de Paulo Menezes. Petrópolis: Vozes, 2001.

HORKHEIMER, M. "Schopenhauers Denken im Verhältnis zu Wissenschaft und Religion”. In:___. Gesammelte Schriften. vol. 7:

Voträge und Aufzeichnungen 1949-1973. Org. de Alfred Schmidt

e Gunzelin Schmid Noerr. Frankfurt: Fischer Taschenbuch Verlag, 1985.

SCHOPENHAUER, A. Sämtliche Werke. Leipzig: Grisebach.

. Sobre o fundamento da moral. Trad. de Maria Lúcia Cacciola. São Paulo: Martins Fontes, 1995. 